\title{
TECHNICAL SERVICES IN THE 21ST CENTURY
}




\section{ADVANCES IN LIBRARY ADMINISTRATION AND ORGANIZATION}

\section{Series Editor: Samantha Schmehl Hines}

\section{Recent volumes:}

Volume 1: $\quad$ Edited by W. Carl Jackson, Bernard Kreissman and Gerard B. McCabe

Volumes 2-12: $\quad$ Edited by Bernard Kreissman and Gerard B. McCabe

Volumes 13-20: Edited by Edward D. Garten and Delmus E. Williams

Volume 21-24: Edited by Edward D. Garten, Delmus E. Williams and James M. Nyce

Volume 25: $\quad$ Edited by Edward D. Garten, Delmus E. Williams, James M. Nyce and Sanna Talja

Volume 26: $\quad$ Edited by Edward D. Garten, Delmus E. Williams, James M. Nyce and Janine Golden

Volume 27: $\quad$ Edited by William Graves III, James M. Nyce, Janine Golden and Delmus E. Williams

Volume 28: $\quad$ Edited by Delmus E. Williams, James M. Nyce and Janine Golden

Volume 29: $\quad$ Edited by Delmus E. Williams and Janine Golden

Volume 30: $\quad$ Edited by Delmus E. Williams and Janine Golden

Volume 31: $\quad$ Edited by Delmus E. Williams and Janine Golden

Volume 32: $\quad$ Edited by Delmus E Williamsand Janine Golden

Volume 33: $\quad$ Edited by Delmus E Williams, Janine Golden and Jennifer K. Sweeney

Volume 34: $\quad$ Edited by Samantha Schmehl Hines and Marcy Simons

Volume 35: $\quad$ Edited by David Baker and Wendy Evans

Volume 36: $\quad$ Edited by Samantha Schmehl Hines and Kathryn Moore Crowe

Volume 37: $\quad$ Edited by Samantha Schmehl Hines and Miriam Matteson

Volume 38: $\quad$ Edited by Samantha Schmehl Hines and Alice Daugherty

Volume 39: $\quad$ Edited by Samantha Schmehl Hines and George J Fowler

Volume 40: $\quad$ Edited by Samantha Schmehl Hines and Janet A Crum

Volume 41: $\quad$ Edited by Samantha Schmehl Hines 
ADVANCES IN LIBRARY ADMINISTRATION AND ORGANIZATION VOLUME 42

\title{
TECHNICAL SERVICES IN THE 21ST CENTURY
}

\author{
EDITED BY \\ SAMANTHA SCHMEHL HINES
}

Peninsula College, Port Angeles, USA

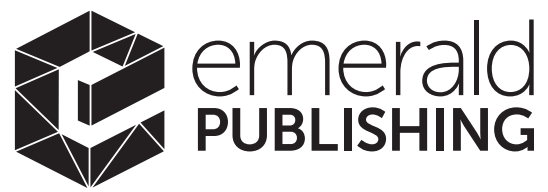

United Kingdom - North America - Japan India - Malaysia - China 
Emerald Publishing Limited

Howard House, Wagon Lane, Bingley BD16 1WA, UK

First edition 2021

Copyright (C) 2021 Emerald Publishing Limited

\section{Reprints and permissions service}

Contact: permissions@emeraldinsight.com

No part of this book may be reproduced, stored in a retrieval system, transmitted in any form or by any means electronic, mechanical, photocopying, recording or otherwise without either the prior written permission of the publisher or a licence permitting restricted copying issued in the UK by The Copyright Licensing Agency and in the USA by The Copyright Clearance Center. Any opinions expressed in the chapters are those of the authors. Whilst Emerald makes every effort to ensure the quality and accuracy of its content, Emerald makes no representation implied or otherwise, as to the chapters' suitability and application and disclaims any warranties, express or implied, to their use.

\section{British Library Cataloguing in Publication Data}

A catalogue record for this book is available from the British Library

ISBN: 978-1-80043-829-3 (Print)

ISBN: 978-1-80043-828-6 (Online)

ISBN: 978-1-80043-830-9 (Epub)

ISSN: 0732-0671

ISOQAR certified

Management System

awarded to Emerald

for adherence to

Environmental

standard

ISOQAR

ISO 14001:2004.

Certificate Number 1985 


\section{CONTENTS}

List of Contributors

$v i i$

Introduction

1

Samantha Schmehl Hines

Guiding Principles for Technical Services through a Content Analysis of Strategic Plans

Abigail Bibee, Erin Gallagher and David Isaak

More than Meets the Eye: Technical Services Work as Outreach 21

Whitney A. Buccicone and Kristin Browning Leaman

Complex Adaptive Systems in Technical Services: A Functional Model for Assessing Institutional Alignment

Nina Servizzi

Process Mapping and High Performance Management in Technical Services

Kristy White

Faculty Workload Guidelines in Technical Services

Aimée deChambeau, Ian McCullough, Melanie McGurr and Mike Monaco

Life Cycle Package Management for Print and Electronic Resources: Cross-training a Customer-oriented Technical Services Team

Beth Ashmore, Maria Collins, Christenna Hutchins and Lynn Whittenberger 
Two Separate Worlds, One Shared Goal: An Exploration of Special Collections Catalogers' Reporting Lines and Institutional Organization

Colleen W. Barrett, Whitney A. Buccicone and

Joseph J. Shankweiler

You Are What You Measure

Sarah Theimer

Moving Toward BIBFRAME and a Linked Data Environment 131 Misu Kim, Mingyu Chen and Debbie Montgomery

Data of E-Resources: Moving Forward with Assessment Jessica Urick Oberlin

From Silo to the Web: Library Cataloging Data in an Open Environment

Jo Williams

The Death of the Big Deal and Implications for Technical Services

Angela Maranville and Karen Diaz

Purchasing Models for Streaming Film: Attitudes and

Motivation

Lindsey Reno

About the Authors

Index 


\section{LIST OF CONTRIBUTORS}

Beth Ashmore

Colleen W. Barrett

Abigail Bibee

Whitney A. Buccicone

Mingyu Chen

Maria Collins

Aimée deChambeau

Karen Diaz

Erin Gallagher

Christenna Hutchins

David Isaak

Misu Kim

Kristin Browning Leaman

Angela Maranville

Ian McCullough

Melanie McGurr

Mike Monaco

Debbie Montgomery

Jessica Urick Oberlin

Lindsey Reno

Nina Servizzi

Joseph J. Shankweiler

Sarah Theimer

Kristy White

Lynn Whittenberger

Jo Williams
North Carolina State University Libraries, USA

University of Kentucky, USA

University of Arizona Libraries, USA

University of Virginia, USA

University of Texas at Dallas, USA

North Carolina State University Libraries, USA

The University of Akron, USA

West Virginia University Libraries, USA

University of Florida Libraries, USA

North Carolina State University Libraries, USA

Reed College Library, USA

University of Texas at Dallas, USA

Indiana University, USA

West Virginia University Libraries, USA

The University of Akron, USA

The University of Akron, USA

The University of Akron, USA

University of Texas at Dallas, USA

Pennsylvania College of Technology, USA

University of New Orleans, USA

New York University Division of Libraries, USA

Western Kentucky University, USA

University of New Hampshire, USA

Duquesne University, USA

North Carolina State University Libraries, USA

Middle Tennessee State University, USA 